\title{
LOWER URINARY TRACT DYSFUNCTION IN CHILDREN AND ADOLESCENTS
}

- family impact•

\author{
Martha Moreira Cavalcante Castro*/**, Maíssa Andrade*, Vanessa Xavier*, Juliana Bonfim*, \\ Lilian Bastos*, Carla Daltro**, Patricia Lordelo*, Ubirajara Barroso*/** \\ Corresponding author: Martha Moreira Cavalcante Castro e-mail: marthamccastro@gmail.com \\ * Escola Bahiana de Medicina e Saúde Pública, Salvador BA,Brasil; \\ ** Universidade Federal da Bahia, Salvador BA, Brasil.
}

\begin{abstract}
The dysfunction of the lower urinary tract (DTUI) is an abnormal pattern of the urinary control with loss of coordinated capacity storage, stocking and elimination of urine. In order to assess the impact of lower urinary tract dysfunction in their child's caregivers, this series was performed to evaluate 30 cases of caregivers of children with voiding disorders. Applied HAD scales and SF-36. Of these, $60 \%(n=18)$ had anxiety symptoms and $43.3 \%(n=13)$ depressive symptoms. Despite the scale items of quality of life was above average, the items pain, general health, vitality, emotional limitations and mental health measures were below the average. Thus, the effect of voiding dysfunction in parents of children affects the mood and quality of life in their daily lives.
\end{abstract}

Kepwords: Children; Dysfunction; Family; Quality of life. anxiety.

\section{INTRODUCTION}

The dysfunction of the lower urinary tract (DTUI) is recognized as an abnormal pattern for the age of the child that should get the urinary control, in which it presents loss of coordinated capacity storage, stocking and elimination of urine during the day and night. In DTUI for overactive bladder, it may be difficult to contain urine, cause urinary infections (UI) and aggravate the vesicoureteral reflux, and may cause kidney problems in the future due to the appearance of severe scars. ${ }^{(1)}$

The DTUI occurs when, in the absence of neurological and anatomical disorders of the lower urinary tract, one of the components of the normal urination process is affected and does not work seamlessly due to changes in the cortex, brainstem, spinal cord, detrusor or on 
the sphincter complex, causing an inadequate urine storage and / or incomplete bladder emptying. ${ }^{(2)}$

In most cases, the parents and guardians of children have difficulty in reporting the symptoms, due to lack of knowledge of the problem, considering the symptoms as normal actions generated by the individual in day to-day. Even so, usually, when the doctor is sought, which motivates the query are urinary losses during the night and all the trouble caused by the episode, such as sleep disruption of parents, children's social isolation, the loss of sheets, mattresses and pajamas, the difficulty in performing sports, among other things. (3,4)

Many parents think that the DTUI symptoms are due to laziness of the child and some even punish them because of it. The relationship between parents and children who have urinary incontinence can be turbulent, and can sometimes be painful for their parents and, on many occasions, they will need support of various kinds, whether material, emotional, informational, affective, or social exchange(5) This study aimed to evaluate the impact of DTUI in the family through research of caregivers and / or guardians.

\section{MATERIAL AND METHODS}

A case series study with a convenience sample that evaluated caregivers or guardians who accompanied the children under treatment at the Center for urination disorders in Childhood (CEDIMI). In this center, children with urinary incontinence due to any cause, from those without neurological damage to those with neuropathic problems. The research was conducted in the period from May to November, 2011. The evaluations were carried out after the signing of the Informed Consent Form and using as instruments; Psychological interview; HAD Scale - this scale has 14 items, 07 to anxiety and o7 for depression, and has as cutoff, 8 for anxiety and 9 for depression $^{(6)}$ and the Quality of Life Scale SF-36.(7)

For the building of the database and statistical calculations we used the software Statistical Package for Social Sciences (SPSS). The quantitative variables were expressed as mean and standard deviation or median and interquartile range (IQR). The results of the categorical variables were expressed as proportions and to study them we used the Pearson's chi-square test. Were considered as significant values of $p<0.05$.

This study was approved by the Ethics Committee in Research Escola Bahiana de Medicina e Saúde Pública (EBMSP) / Fundação Bahiana para Desenvolvimento das Ciências (FBDC) with the research protocol number 148/2010.

\section{RESULTS}

We interviewed 30 parents / caregivers of children with voiding disorders. Table 1 shows the general characteristics of children treated in CEDIMI with regard to age, number of siblings, educational level and the presence of any voiding disorder or DTUI. (Table 1)

Table 2 shows the general characteristics of 30 parents / guardians evaluated with regard to marriage, religiosity and impact of voiding disorder of the children and its treatment in their lives.

As for the response of the Hospital Anxiety and Depression Scale (HAD), the results showed that, of the parents / guardians evaluated, 18 (60\%) demonstrated anxiety symptoms, while 13 (43.3\%) demonstrated depressive symptoms. Regarding quality of life, when analyzing the median score was seen that all the items of the scale showed above the average range $(50 \%)$ being the most negatively affected: vitality, emotional limitations, general health condition and pain. (Table 3) 
Table 1 - Clinical and socio-demographic characteristics of children followed up at CEDIMI, 2011

\begin{tabular}{lc}
\hline ChaRACTERIStics & Results \\
Age (Md; IQR) & $9(7.0 ; 11.0)$ \\
Siblings & $25(83,3 \%)$ \\
Educational level & \\
Basic education & $27(90 \%)$ \\
High school & $3(10 \%)$ \\
Satisfactory school performance & $16(53.3 \%)$ \\
Interference in school & $9(30 \%)$ \\
Onset of symptoms & \\
To the birth & $16(53.3 \%)$ \\
Up to 2 years old & $5(16.7 \%)$ \\
Up to 4 years old & $5(16.7 \%)$ \\
Up to 6 years old & $1(3.3 \%)$ \\
Up to 8 years old & $3(10 \%)$ \\
& \\
\hline
\end{tabular}

Table 2 - Characteristics of parents / guardians of children followed up at CEDIMI, 2011

\begin{tabular}{lc}
\hline CHARACTERISTICS & RESULTS \\
Stable union & $12(40.0 \%)$ \\
Satisfactory relationship of parents & $14(46.7 \%)$ \\
Religion & $23(76.7 \%)$ \\
How the family deals with the DTUI & \\
Believes and seeks help & $21(70.0 \%)$ \\
Does not believe & $9(30.0 \%)$ \\
DTUI knowledge possessed before treatment & $5(16.7 \%)$ \\
Difficulties encountered in the treatment & $13(43.3 \%)$ \\
No & $8(26.7 \%)$ \\
Procedures & $7(23.3 \%)$ \\
Alimentation & $2(6.7 \%)$ \\
Physiotherapy & $7(23.3 \%)$ \\
DTUl interfering in the relationship with spouse, social and & $30(100.0 \%)$ \\
with the child. & $29(96.7 \%)$ \\
Feeling on the DTUI & $1(3.3 \%)$ \\
Confused, angry or disappointed & \\
Indifferent & \\
Would accept group therapy & \\
\hline
\end{tabular}


Table 3 - Quality of life of those responsible for children and adolescents followed up at CEDIMI, 2011

\begin{tabular}{lc}
\hline VARIABLES & RESULTS \\
SF-36 scale & $70(60 ; 89)$ \\
Functional capacity & $100(50 ; 100)$ \\
Physical limitations & $58,5(41 ; 69)$ \\
Pain & $57(42 ; 73)$ \\
General health status & $55(39 ; 70)$ \\
Vitality & $87,25(62 ; 100)$ \\
Social aspects & $55,8(0 ; 100)$ \\
Emotional limitations & $64(44 ; 76)$ \\
Mental health & \\
\hline
\end{tabular}

*Data expressed as median and interquartile range (Md; IQR)

\section{DISCUSSION}

This study showed that most of those responsible for children with DTUI had no prior knowledge of the disorder, they felt confused, angry, disappointed and had anxious symptoms, although they did not show a great repercussion the quality of life.

The socio-demographic data of the children in this sample were compatible with those found in the literature for age, number of siblings and school performance. ${ }^{(8)}$

The family is an intercom system in which the behavior of one member can only be understood as from a whole system group, modified when occurs transformation in one of its members. When one of their members gets sick, especially when it comes to a child, there is a destructuring of this system, leading to the need for change in their routine in order to adapt to newly stressful situations brought about by the disease. In the face of disease, the family is faced with two tasks: taking care of the person who is ill and deal with the emotions that emerge and begin to transform relations between its members. ${ }^{(9)}$ This can be demonstrated when we observe that more than half of the parents or guardians showed up anxious, while a smaller percentage had depressive symptoms in this study.

The DTUI is a chronic disease with long stroke, characterized mainly by urinary incontinence, leaving sequelae and imposing limitations on the functions of the individual and family. It is important to emphasize that patients with chronic disease may have a life of physical limitations, emotional and social, also affecting their parents and guardians. The child chronic disease reacts in different ways to the disease process, which may cause feelings of guilt, fear, anxiety, depression, apathy, besides threatening the routine of his/her day-to- day. ${ }^{(10,11)}$

The earlier the diagnosis is established, a better understanding of the parents and child about the disease, and consequently, better treatment adherence. It is noteworthy that, for the health care team, the data collection is extremely necessary for an understanding of the clinical picture, thus examining the biopsychosocial changes occasioned by the same. Thus, a detailed interview and technically well grounded is essential in the evaluation of these patients. ${ }^{(12)}$

Dealing with the illness of a child, and when it becomes a chronic disease, requires from this family a series of amendments ranging from the recognition of the disorder to diagnosis and treatment of morbidity. It often happens that, family members and patients are gripped by fear and anguish of illness. As a result of this emotional shock and the limitations and implications arising from the disease, family members may reveal feelings of anger, confusion and disappointment facing the DTUI, as seen in this study in the vast majority of those responsible. This family system 
has to adapt to make this transition less troubled. It is necessary for the family to be active in this new routine of treatments, in order to help the son to accept the disorder and adhere to treatment. ${ }^{(2)}$

In the face of chronic illness of the child, the family may be affected, as well as social relations, occupational, educational and professional, due to the need of daily care. Due maternal care that children with chronic illness may need, the mother often abandons her job, directing her efforts just to her son. In this study few responsible reported that the DTUI interfered in the relationship with spouse, social and with the child. The mother who takes care of the patient can change her role as wife and Woman and centralize in the role of caregiver. Because of this, the probability of exhaustion and emotional problems is bigger, and may present social isolation, aggressiveness in the marital relationship, anger, desire that the father be more active in the care of the child, emotional overload, physical and also financial, as well as unleash disturbances at the level of mental health and psychological well - being. ${ }^{(13)}$

It is noticed that the family has no means to resolve conflicts, these are experienced in a distressing way and the family group avoids facing them. It is common in certain families, that the mother engages in too much with the patient, neglecting the needs of other elements. These parents' attempts to avoid conflicts, involving the child in discussions, aim to decrease the familiar "stress". (14)

Some parents have difficulties in understanding the problem of the child as they consider that the child is lazy and careless. Thus, they become intolerant using verbal and physical agressions that only tend to worsen the problem. Thus, it emphasizes the importance of family support for the child's emotional development, given that the same has a lowering of self-esteem, causing a decrease of the notion of identity and perception of reality. ${ }^{(15)}$

It is necessary to accompany the parents so that they can understand their conflicts and guide their children properly. With psychological orientation, the parents feel supported and informed about the correct approach to the sphincter education in order to be assisted to face and understand the problem faced by the son. ${ }^{(16)}$ This can be justified by all responsible interviewed relate to accept group therapy, showing that are open to try to modify the default behavior

The concept of quality of life is recognized by the involvement of biological, psychological, social and spiritual aspects. The quality of life entails categories related to physical and emotional balance; leisure and recreation; interpersonal relationships; professional activity and productivity; personal and environmental hygiene; safety and so on. It is understood that, to maintain the wellbeing of the patient affected by chronic disease alleviating his/her suffering, it is necessary that the professionals involved in the process when performing interventions, take into consideration the subject's subjectivity. ${ }^{(17)}$

During the phases of the chronic illness, the family goes through many difficult and stressful moments that alone, might not be able to overcome and have the strength to move on. The answers in these situations imposed by the disease can be greatly influenced by the social network and support that families have and resort in the most varied moments. Although the family is with arms wide open to receive this support, yet perceives it as insufficient, despite its importance in overcoming the obstacles imposed by the chronicity of the disease, especially when there is need for many precautions that overload their members, stressing them. Whenever the family is supported, helped, assisted by people who are available at certain times of life, they are getting the social support necessary and essential to supply their needs momentarily. ${ }^{(3)}$

\section{CONCLUSIONS}

In this study it was shown that the family that deals with children with DTUI, regarding the disease reveals feelings of confusion, irritability and disappointment; presents median quality of life and shows receptive to conduct group psychotherapy. We then suggest this family to be welcomed and 
served so that they can learn to deal with this dysfunction by decreasing the effects it causes in their lives.

\section{REFERENCES}

1. Mota D, Victora C, Hallal P. Investigação de disfunção miccional em amostra populacional de crianças de 3 a 9 anos. J. Pediatr. 2005;81supp | 2:219-231.

2. Fonseca EMGO, Monteiro LMC. Diagnóstico clínico de disfunção miccional em crianças e adolescentes enuréticos. J. Pediatr. 2004;80 supp | 2:147-153.

3. Pahl M, Ejzenberg B, Ragazzi, S, Machado B, Pedra C, Baldacci E, et al. Tratamento ambulatorial de crianças com infecção urinária complicada. J. Pediat. 1996; 72 suppl 5:303-310.

4. Mota DM, Barros AJD. Treinamento esfincteriano: métodos, expectativas dos pais e morbidades associadas. J. Pediatr. 2008;84 suppl 1:9-17.

5. Nóbrega VM, Collet N, Silva KL, Coutinho, SED. Rede e apoio social das famílias de crianças em condição crônica. Rev. Eletrônica de Enferm. 2010;12 suppl 3:431-440.

6. Botega NJ, Pondé, MP Medeiros P, Lima MG, Guerreiro CAM. Validação da escala hospitalar de ansiedade e depressão (HAD) em pacientes epilépticos ambulatoriais. J. Bras. Psiquiatr. 1998; 47 suppl 6:285-289.

7. Ciconelli RM. Tradução para o português e validação do questionário genérico de avaliação de qualidade de vida "Medical outcomes study 36-item short-form health survey (SF-36)" [Tese]. São Paulo: Escola Paulista de Medicina Universidade Federal de São Paulo; 1997.

8. Piccinini CA, Castro EK, Alvarenga P, Vargas S, Oliveira VZ. A doença crônica orgânica na infância e as práticas educativas maternas. Estud. Psicol. 2003;8 suppl 1:75-83.

9. Ferro FO, Amorim, VCO. As emoções emergentes na hospitalização infantil. Rev Eletrônica Psicol. 2007;1(1).

1O. Vieira MA, Lima RA. Crianças e Adolescentes com doença crônica: convivendo com mudanças. Rev Latinam Enferm. 2002;10, suppl 4:552-560.

11. Rangel RA. Avaliação da qualidade de vida em crianças com enurese noturna. [Tese]. Juiz de Fora: Universidade Federal de Juiz de Fora; 2009.

12. Péres DS. Representações sociais de mulheres diabéticas, de camadas populares, em relação ao processo saúde-doença. Ver Latinoam Enfer. [Internet]. 2008; 16, suppl. 3, Disponível em: http://www.scielo.br/pdf/rlae/v16n3/pt_09.pdf

13. Rolland J. Doença crônica e o ciclo da vida familiar. In: Carter B, Mcgoldrick M. As mudanças no ciclo de vida familiar. São Paulo. Artmed, 2010. pp. 90-101.

14. Lopez M, Stuhler G. Atendimento psicológico a mães de crianças com doença crônica: relato de experiência. Psicol Argum. 2008;26 suppl 55:341-347.

15. Santos EOL, Silvares EFM. Crianças enuréticas e crianças encaminhadas para clinicas-escola: um estudo comparativo da percepção de seus pais. Psicol Reflex Crit. 2006; 19 suppl 2:77282.

16. Oliveira AS, Bermudez CC, Souza RA, Souza CMA, Dias EM, Castro CES. Pain impacto life of patients with temporomandibular disorder. J. Appl. Oral Sci. 2003; 11 suppl 2: 138-143.

17. Martins LM, Franca APD, Kimura, M. Qualidade de vida de pessoas com doença crônica. Rev Latinoam Enferm. 1996;4 suppl 3:5-18. 